\title{
Perspectives on Sustainable Integrated Clean Environment for Human and Nature
}

\author{
Shervin Hashemi (D)
}

Citation: Hashemi, S. Perspectives on Sustainable Integrated Clean

Environment for Human and Nature.

Sustainability 2021, 13, 4150.

https://doi.org/10.3390/su13084150

Received: 6 April 2021

Accepted: 7 April 2021

Published: 8 April 2021

Publisher's Note: MDPI stays neutral with regard to jurisdictional claims in published maps and institutional affiliations.

Copyright: (C) 2021 by the author. Licensee MDPI, Basel, Switzerland. This article is an open access article distributed under the terms and conditions of the Creative Commons Attribution (CC BY) license (https:// creativecommons.org/licenses/by/ $4.0 /)$.
Institute for Environmental Research, Yonsei University College of Medicine, 50-1 Yonsei-ro, Seodae-mun-gu, Seoul 03722, Korea; shervin@yuhs.ac

\section{Introduction}

The term "sustainability" is generally used to describe an ideal condition in which the Earth's biosphere and human civilization can safely interact and coexist [1]. Accordingly, it is essential to have a comprehensive vision of the requirements for a clean environment sustainable by humans and nature. Such a vision can be useful as it encompasses all aspects related to human life that interact with nature, so that human civilization can develop while respecting and protecting nature.

However, there are limited scientific approaches to achieving this vision. To address this knowledge gap, in December 2019, the author proposed a Special Issue of the journal Sustainability (ISSN 2071-1050) entitled "Sustainable Integrated Clean Environment for Human \& Nature", to gather the missing pieces of this vision among multidisciplinary scientific-technical, economic, and social approaches over a one-year period. The Special Issue attempts to answer the following key questions:

1. What is the current condition of our environment? Is it clean and pollution-free?

2. How can we make our environment clean and suitable for humans and nature?

3. How can we sustainably keep our environment clean?

The articles in the Special Issue contribute to one or more of the following fields:

- Actions for developing countries;

- Clean technologies;

- Economic approaches;

- Environmental remediation;

- Global water security issues;

- Hazardous substances;

- Human-nature interactions;

- Nature-based solutions-from theories and laboratories to fields and actions;

- New policies;

- Public health;

- $\quad$ Risk assessment and modeling;

- $\quad$ Sanitation/hygiene;

- Social awareness/human rights-concepts of leaving no one behind, pilot social studies, reactions from different societies;

- Sustainable water, wastewater, and waste treatment, including pilot scaled case studies;

- Resource circulation-conservation and recycling.

\section{List of Contributions}

Over 30 manuscripts were submitted for consideration for the Special Issue, and all of them underwent the journal's rigorous review process. In total, 19 papers, including 17 research articles and 2 review papers, were finally accepted for publication and inclusion in this Special Issue. These are listed below: 
1. Al-Gheethi, A.; Al-Sahari, M.; Abdul Malek, M.; Noman, E.; Al-Maqtari, Q.; Mohamed, R.; Talip, B.A.; Alkhadher, S.; Hossain, M.S. Disinfection Methods and Survival of SARS-CoV-2 in the Environment and Contaminated Materials: A Bibliometric Analysis. Sustainability 2020, 12, 7378. https:/ / doi.org/10.3390/su12187378.

2. Amnuaylojaroen, T.; Inkom, J.; Janta, R.; Surapipith, V. Long Range Transport of Southeast Asian PM2.5 Pollution to Northern Thailand during High Biomass Burning Episodes. Sustainability 2020, 12, 10049. https:/ / doi.org/10.3390/su122310049.

3. Blazy, R.; Hrehorowicz-Gaber, H.; Hrehorowicz-Nowak, A.; Płachta, A. The Synergy of Ecosystems of Blue and Green Infrastructure and Its Services in the Metropolitan Area-Chances and Dangers. Sustainability 2021, 13, 2103. https://doi.org/10.3390/ su13042103.

4. Coccia, M. How (Un)sustainable Environments Are Related to the Diffusion of COVID19: The Relation between Coronavirus Disease 2019, Air Pollution, Wind Resource and Energy. Sustainability 2020, 12, 9709. https: / / doi.org/10.3390/su12229709.

5. Gopalakrishnan, Y.; Al-Gheethi, A.; Abdul Malek, M.; Marisa Azlan, M.; Al-Sahari, M.; Radin Mohamed, R.M.S.; Alkhadher, S.; Noman, E. Removal of Basic Brown 16 from Aqueous Solution Using Durian Shell Adsorbent, Optimisation and Techno-Economic Analysis. Sustainability 2020, 12, 8928. https:/ / doi.org/10.3390/su12218928.

6. Hashemi, S. Sanitation Sustainability Index: A Pilot Approach to Develop a CommunityBased Indicator for Evaluating Sustainability of Sanitation Systems. Sustainability 2020, 12, 6937. https://doi.org/10.3390/su12176937.

7. Hassan, A.; G Almatar, M.; Torab, M.; Allen, C.D. Environmental Urban Plan for Failaka Island, Kuwait: A Study in Urban Geomorphology. Sustainability 2020, 12, 7125. https:// doi.org/10.3390/su12177125.

8. Kärenlampi, P.P. Diversity of Carbon Storage Economics in Fertile Boreal Spruce (Picea Abies) Estates. Sustainability 2021, 13, 560. https: / / doi.org/10.3390/su13020560.

9. Li, Y.; Wang, X.; Dong, X. Delineating an Integrated Ecological and Cultural Corridor Network: A Case Study in Beijing, China. Sustainability 2021, 13, 412. https:/ / doi. org/10.3390/su13010412.

10. Mofijur, M.; Rizwanul Fattah, I.M.; Saiful Islam, A.B.M.; Uddin, M.N.; Ashrafur Rahman, S.M.; Chowdhury, M.A.; Alam, M.A.; Uddin, M..A. Relationship between Weather Variables and New Daily COVID-19 Cases in Dhaka, Bangladesh. Sustainability 2020, 12, 8319. https: / / doi.org/10.3390/su12208319.

11. Muliadi, F.N.A.; Halmi, M.I.E.; Wahid, S.B.A.; Gani, S.S.A.; Mahmud, K.; Shukor, M.Y.A. Immobilization of Metanil Yellow Decolorizing Mixed Culture FN3 Using Gelling Gum as Matrix for Bioremediation Application. Sustainability 2021, 13, 36. https:// doi.org/10.3390/su13010036.

12. Muliadi, F.N.A.; Halmi, M.I.E.; Wahid, S.B.A.; Gani, S.S.A.; Zaidan, U.H.; Mahmud, K.; Abd Shukor, M.Y. Biostimulation of Microbial Communities from Malaysian Agricultural Soil for Detoxification of Metanil Yellow Dye; a Response Surface Methodological Approach. Sustainability 2021, 13, 138. https:/ / doi.org/10.3390/su13010138.

13. Nur-E-Alam, M.; Hoque, M.N.; Ahmed, S.M.; Basher, M.K.; Das, N. Energy Engineering Approach for Rural Areas Cattle Farmers in Bangladesh to Reduce COVID-19 Impact on Food Safety. Sustainability 2020, 12, 8609. https:/ / doi.org/10.3390/su122 08609.

14. Rahman, M.; Thill, J.-C.; Paul, K.C. COVID-19 Pandemic Severity, Lockdown Regimes, and People's Mobility: Early Evidence from 88 Countries. Sustainability 2020, 12, 9101. https://doi.org/10.3390/su12219101.

15. Roblek, V.; Thorpe, O.; Bach, M.P.; Jerman, A.; Meško, M. The Fourth Industrial Revolution and the Sustainability Practices: A Comparative Automated Content Analysis Approach of Theory and Practice. Sustainability 2020, 12, 8497. https:/ / doi. org /10.3390/su12208497. 
16. Scharf, M.; Heide, L.; Grahle, A.; Syré, A.M.; Göhlich, D. Environmental Impact of Subsidy Concepts for Stimulating Car Sales in Germany. Sustainability 2020, 12, 10037. https:/ / doi.org/10.3390/su122310037.

17. Tanveer, M.; Hassan, S.; Bhaumik, A. Academic Policy Regarding Sustainability and Artificial Intelligence (AI). Sustainability 2020, 12, 9435. https:/ / doi.org/10.3390/su1 2229435.

18. White, I.; Falkland, T.; Kula, T. National Versus Local Sustainable Development Plans and Island Priorities in Sanitation: Examples from the Kingdom of Tonga. Sustainability 2020, 12, 9379. https:/ / doi.org/10.3390/su12229379.

19. Woo, B.L.; Lim, M.K.; Park, E.Y.; Park, J.; Ryu, H.; Jung, D.; Ramirez, M.J.; Yang, W. Characteristics of Non-Smokers' Exposure Using Indirect Smoking Indicators and Time Activity Patterns. Sustainability 2020, 12, 9099. https://doi.org/10.3390/su122 19099.

\section{Content and Significance of Contributions}

Shortly after the Special Issue was announced, the world faced one of the most serious outbreaks of severe acute respiratory syndrome coronavirus 2 (SARS-CoV-2) [2]. In view of humanity's current lifestyle, the coronavirus disease (COVID-19) pandemic has shown the fragility of our concept of sustainability [3]. Consequently, the importance of the concept of "sustainable, clean environment" became clear to individuals around the world.

The COVID-19 pandemic has demonstrated the need for a crucial reconsideration of the need for a sustainable, clean environment for humans and nature. The provision of safe water, sanitation, hygiene, and waste management is essential for preventing virus transmission, and protecting human health has become increasingly critical. Understanding the technical, social, and economic concepts of the COVID-19 pandemic and recognizing challenges can lead to solutions and sustainable management approaches during and after the pandemic.

In response to the COVID-19 pandemic, contributions 1, 4, 10, 13, and 14 cover a wide range of topics related to the sustainability of an integrated clean environment. These contributions are useful in highlighting the novel meaning of sustainability after the COVID-19 pandemic.

Accordingly, the 4th Sustainability Webinar, "COVID-19 and the Sustainability of Clean Environment for Human \& Nature: Visions, Challenges, and Solutions", was proposed to provide a global forum for ordinary individuals and decision-makers to understand the vision, challenges, and solutions for sustaining a clean environment for humans and nature during and after the COVID-19 pandemic. The webinar included presentations from four experts, including scholars who made relevant contributions to the Special Issue. A webinar recording is available online at https://sustainability-4.sciforum.net/ (accessed on 29 March 2021) [4].

Along with the medical approaches for overcoming the COVID-19 pandemic, implementing appropriate green technologies may be considered among the highest priorities for sustainable development during and after the COVID-19 pandemic.

The Special Issue contains two contributions on the topic of sustainable sanitation. Contribution 6 introduces the Sanitation Sustainability Index, which is an integrated, community-based indicator for evaluating the sustainability of sanitation systems, which will be implemented in specific communities. The highlighted characteristics of this newly developed index are the consideration of a wider range of sanitation sustainability parameters, including acceptability and public health indicators, and the ability of the index to evaluate sanitation systems before implementation [5].

Another notable contribution is presented by White et al. (contribution 18), who discussed national versus local sustainable development plans and island priorities in sanitation. This article provides examples from the Kingdom of Tonga and presents an analysis of the priorities given to water and sanitation in top-down national sustainable development strategies and nation-wide, bottom-up, village-level community develop- 
ment plans. This contribution has been commended by the editorial office of the journal Sustainability and has been recognized as a feature paper.

Contributions 3, 7, and 17 of the Special Issue present discussions on sustainable urban planning, green infrastructure, and academic policies. Contributions 2 and 19 discuss indoor and outdoor air quality from both technical and public health perspectives. In addition, contributions 15 and 16 present intriguing studies that discuss industrial concerns, including impacts on the environment and sustainable development policies. A significant number of studies, including contributions 5, 8, 9, 11, and 12, discuss different aspects of ecological concerns regarding environmental sustainability, including the technical approaches for the treatment or bioremediation of environmental contaminants.

\section{Conclusions}

The Special Issue "Sustainable Integrated Clean Environment for Human \& Nature" is a collection of articles that investigate the technical, economic, and social shortcomings of the current approaches toward a sustainable integrated clean environment for humans and nature in developing countries; these articles also provide innovative solutions aimed at overcoming the challenges of balancing the current approaches to enhance their sustainability.

Consideration of these studies could be helpful for decision-makers seeking to develop efficient strategies leading to the provision of new and effective sustainability policies by considering both the social development of humans and the need to respect and protect nature sustainably.

Funding: This work received no external funding.

Institutional Review Board Statement: Not applicable.

Informed Consent Statement: Not applicable.

Data Availability Statement: Not applicable.

Acknowledgments: The author wishes to acknowledge the generous support of the journal Sustainability and the publisher MDPI. The author also thanks those who contributed papers to this Special Issue, as well as reviewers and the authorial staff at the journal Sustainability, particularly Liv Zhou, for their time and effort in reviewing, improving, and publishing the articles included in this Special Issue. The author is grateful to Eng. Farid Hashemi for his kind support and encouragement. This Special Issue was edited during the peak of the COVID-19 pandemic. The author would like to express his deepest sympathies to people worldwide who have faced losses due to this pandemic.

Conflicts of Interest: The author declares no conflict of interest.

\section{References}

1. Kuhlman, T.; Farrington, J. What is Sustainability? Sustainability 2010, 2, 3436-3448. [CrossRef]

2. Gorbalenya, A.E.; Baker, S.C.; Baric, R.S.; de Groot, R.J.; Drosten, C.; Gulyaeva, A.A.; Haagmans, B.L.; Lauber, C.; Leontovich, A.M.; Neuman, B.W. The species Severe acute respiratory syndrome-related coronavirus: Classifying 2019-nCoV and naming it SARS-CoV-2. Nat. Microbiol. 2020, 5, 536-544.

3. Barbier, E.; Burgess, J. Sustainability and Development after COVID-19. World Dev. 2020, 135, 105082. [CrossRef] [PubMed]

4. Sustainability Webinar I COVID-19 and the Sustainability of Clean Environment for Human \& Nature: Visions, Challenges, and Solutions. Available online: https:/ / sustainability-4.sciforum.net/ (accessed on 29 March 2021).

5. Narzetti, D.A.; Marques, R.C. Access to Water and Sanitation Services in Brazilian Vulnerable Areas: The Role of Regulation and Recent Institutional Reform. Water 2021, 13, 787. [CrossRef] 